\title{
Effect Of Methanolic Extract of Vernonia Amygdalina on Haematological and Plasma Biochemical Parameters in Male Albino Rats
}

\author{
Oyedeji K.O ${ }^{1}$., Bolarinwa A.F ${ }^{2}$, Akintola A.M ${ }^{3}$ \\ ${ }^{I}$ Department of Physiology, College of Medicine and Health Sciences, Afe Babalola University, Ado-Ekiti, \\ Nigeria. \\ ${ }^{2}$ Department of physiology, College of Medicine, University of Ibadan, Ibadan, Nigeria \\ ${ }^{3}$ Department of physiology, Ladoke Akintola University of Technology, P.M.B. 4000, Ogbomoso, Nigeria.
}

\begin{abstract}
Vernonia amygdalina is a shrub that grows throughout tropical Africa. Several studies have reported the nutritional, anti-malaria and anti-helminthic effects of its extracts; but there is a dearth of information on its effect on blood chemistry. This study was designed to investigate the effect of methanolic extract of Vernonia amygdalina (MEVA) on the haematological and plasma biochemical parameters in male albino rats.

Treatment of rats for 30 days with all the treatment doses $(50 \mathrm{mg} / \mathrm{kg} \mathrm{BW}, 100 \mathrm{mg} / \mathrm{kg} \mathrm{BW}, 150 \mathrm{mg} / \mathrm{kg}$ $B W)$ of MEVA caused no significant ( $p>0.05)$ changes in all the haematological parameters (PCV, RBC, TWBC, Hb, MCHC, MCH, MCV, platelet, neutrophil, lymphocyte, eosinophil, monocyte) values relative to their respective controls. However, treatment of rats with $100 \mathrm{mg} / \mathrm{kg} \mathrm{BW}$ and $150 \mathrm{mg} / \mathrm{kg} \mathrm{BW}$ of MEVA caused significant $(p<0.05)$ increase in albumen levels relative to the control. But treatment of rats with all the treatment doses of MEVA caused significant $(p<0.05)$ decreased in ALT levels relative to the control.

These findings suggest that methanolic extract of Vernonia amygdalina have beneficial potentialities on the blood of male albino rats.
\end{abstract}

Key words: Vernonia amygdalina, Red blood cell, Total white blood cell, Albino rats, Albumin.

\section{Introduction}

Vernonia amygdalina belongs to the family of Asteraceae. It is commonly called "Bitter leaf" in English language, "Shuwaka" in Hausa language, "Onugbu" in Igbo language and "Ewuro" in Yoruba language.

It is a highly appreciated vegetable in West and Central Africa and can be consumed in various dishes (Bosni et al., 1995). Medicinally, the leaves are widely used for fevers and are known as quinine substitute (Challand and Willcox, 2009). It is used to prepare cough medicine in Ghana (Akinpelu, 1991) and the root infusion is taken in Nigeria as an antihelminthic as well as for enteritis and rheumatism (Ainslie, 1937).

Pharmacological studies have shown that the leaf extract of $V$. amygdalina has both hypoglycemic and hypolipidemic properties in experimental animals and so could be used in the management of diabetes, hypertension etc (Akah and Okafor, 1992). The extracts of $V$. amygdalina have been reported to have analgesic and antipyretic effects (Tekoba et al., 2002). The aqueous extract of $V$. amygdalina has also been reported to have anti-oxidant property (Nwajo and Nwokoro, 2004).

However, due to scanty information from literature on the effect of Vernonia amygdalina on haematological and plasma biochemical parameters in albino rats, this study therefore aims at investigating the effect of methanolic extract of Vernonia amygdalina on these aforementioned parameters in male albino rats.

\section{Experimental Animals}

\section{Materials And Methods}

Adult male albino rats weighing between $160 \mathrm{~g}$ and $180 \mathrm{~g}$ bred in the Animal House of Physiology Department, LAUTECH, Ogbomoso were used. They were housed under standard laboratory conditions with a 12 hours daylight cycle and had free access to feed and water; they were acclimatized to laboratory conditions for two weeks before the commencement of the experiments. All experiments were carried out in compliance with the recommendations of Helsinki's declaration on guiding principles on care and use of animals.

\section{Plant Materials}

Fresh specimens of $V$. amygdalina harvested from a local farm in Ogbomoso, Nigeria, were authenticated in the taxonomy unit of the department of pure and Applied Biology, LAUTECH, Ogbomoso. 


\section{Preparation of Methanolic Extract of Vernonia Amygdalina (Meva)}

Large quantities $(1.56 \mathrm{~kg}$ ) of the fresh specimens of $V$. amygdalina were washed free of soil and debris, and the roots were separated from the leaves and stems. The leaves and stems were air-dried for four weeks, and the dried specimens were pulverized using laboratory mortar and pestle.

Weighed portion $(556 \mathrm{~g})$ of the pulverized specimens were macerated with $70 \%$ methanol (1:2 wt./vol.) for 72 hours at room temperature $\left(26-28^{0} \mathrm{C}\right)$. The resulting solution was then filtered using a wire-gauze and a sieve with tiny pores $(0.25 \mathrm{~mm})$. The $70 \%$ methanol was later evaporated using steam bath to give a percentage yield of $10.24 \%$ of the starting material.

Ten grams of the methanolic extract of $V$. amygdalina (MEVA) was dissolved in $100 \mathrm{ml}$ of distilled water to give a concentration of $0.1 \mathrm{~g} / \mathrm{mL}$. The dosages of the extract administered in this study were in accordance with those reported by Challand and Willcox (2009).

\section{Experimental Design}

Twenty-four animals were randomly divided into four groups with each group consisting of six rats. The four groups of rats were subjected to the following oral treatments once a day for 30 days:

Group I rats received $50 \mathrm{mg} / \mathrm{kg}$ BW of MEVA

Group II rats received $100 \mathrm{mg} / \mathrm{kg}$ BW of MEVA

Group III rats receive $150 \mathrm{mg} / \mathrm{kg}$ BW of MEVA

Group IV rats received $0.5 \mathrm{ml}$ of distilled water as the control group.

Twenty-four hours (day 31) after the last dosing of the four groups, blood samples were collected.

\section{Collection of Blood Sample}

Blood samples were collected through the medial cantus into EDTA bottles for haematological and plasma biochemical studies. Before assays, the blood samples were centrifuge for 5 minutes using a bench-top centrifuge (Centromix) and the supernant plasma was then used for the determinations of the biochemical parameters.

\section{Determination of Haematological Parameters}

The red blood cells (RBC) and white blood cells (WBC) counts were determined by the improved Neubauer haemocytometer method. The haemoglobin $(\mathrm{Hb})$ concentration was determined according to Jain (1986), using the cyanomethaemoglobin method. The packed cell volume (PCV) was determined by the microhaematocrit method according to Dacie and Lewis (1991). Schilling method of differential lecukocyte count was used to determine the distribution of the various white blood cells (Mitruka and Rawnsley, 1977). Mean corpuscular volume $(\mathrm{MCV})$, mean corpuscular haemoglobin $(\mathrm{MCH})$ and mean corpuscular haemoglobin concentration (MCHC) were computed according to Jain (1986).

\section{Determination of Plasma Biochemical Parameters}

The total protein concentration was determined using the Biuret method (Reinhold, 1953) and the albumin concentration by the method of Doumas et al. (1971). The globulin concentration was calculated by subtracting the albumin concentration from the total protein concentration. Activities of plasma alanine transaminase (ALT) and aspartate transaminase (AST) were determined according to the method of Duncan (1994). The level of cratinine was determined using the method of Tietz et al. (1994). All the above biochemical parameter were determined in the plasma using the Randox kits.

\section{Statistical Analysis}

The mean and standard error of mean (S.E.M.) were calculated for all values. Comparison between the control and experimental groups was done using one-way analysis of variance (ANOVA) with Duncan's Multiple Range Test. Differences were considered statistically significant at $\mathrm{p}<0.05$.

\section{Results}

Treatment of rats for 30 days with $50 \mathrm{mg} / \mathrm{kg} \mathrm{BW}, 100 \mathrm{mg} / \mathrm{kg} \mathrm{BW}$ and $150 \mathrm{mg} / \mathrm{kg} \mathrm{BW}$ of MEVA caused non-significant $(\mathrm{p}<0.05)$ changes in $\mathrm{PCV}, \mathrm{Hb}, \mathrm{RBC}, \mathrm{MCV}, \mathrm{MCHC}, \mathrm{MCH}$, TWBC, platelet, neutrophil, lymphocyte, eosinophil and monocyte values relative to their respective controls.

Treatment of rats with $100 \mathrm{mg} / \mathrm{kg} \mathrm{BW}$ of MEVA caused significant $(\mathrm{p}<0.05)$ decreases in globulin and total protein levels, while $100 \mathrm{mg} / \mathrm{kg} \mathrm{BW}$ and $150 \mathrm{mg} / \mathrm{kg} \mathrm{BW}$ of MEVA produced significant $(\mathrm{p}<0.05)$ increases in albumin levels relative to the control. Treatment of rats with $50 \mathrm{mg} / \mathrm{kg} \mathrm{BW}, 100 \mathrm{mg} / \mathrm{kg} \mathrm{BW}$ and $150 \mathrm{mg} / \mathrm{kg}$ of MEVA caused significant $(\mathrm{p}<0.05)$ reductions in the activities of ALT relative to the control. The administration of all the treatment doses of MEVA caused no significant $(p>0.05)$ changes in the levels and activities of creatinine and AST relative to their controls respectively. 
Table 1: Effect of 30 days treatment with varying doses of MEVA on haematological parameters $(\mathrm{n}=6, * \mathrm{p}<0.05)$

\begin{tabular}{lllll}
\hline Parameters & Control & $50 \mathrm{mg} / \mathrm{kg}$ & $100 \mathrm{mg} / \mathrm{kg}$ & $150 \mathrm{mg} / \mathrm{kg}$ \\
\hline $\mathrm{PCV}(\%)$ & $50.20 \pm 1.88$ & $47.20 \pm 1.96$ & $50.60 \pm 1.83$ & $51.04 \pm 1.21$ \\
$\mathrm{Hb}(\mathrm{g} / \mathrm{dl})$ & $15.54 \pm 0.50$ & $14.82 \pm 0.67$ & $15.94 \pm 0.77$ & $15.88 \pm 0.41$ \\
$\mathrm{RBC}\left(\times 10^{6} / \mu \mathrm{L}\right)$ & $7.91 \pm 0.32$ & $7.41 \pm 0.29$ & $8.05 \pm 0.37$ & $8.33 \pm 0.25$ \\
$\mathrm{MCV}(\mathrm{FL})$ & $63.51 \pm 1.01$ & $63.69 \pm 0.87$ & $63.07 \pm 1.44$ & $61.70 \pm 0.47$ \\
$\mathrm{MCHC}(\mathrm{g} / \mathrm{dL})$ & $31.00 \pm 0.56$ & $31.38 \pm 0.21$ & $31.45 \pm 0.45$ & $30.89 \pm 0.32$ \\
$\mathrm{MCH}(\mathrm{pg})$ & $19.67 \pm 0.20$ & $19.99 \pm 0.41$ & $19.83 \pm 0.47$ & $19.08 \pm 0.24$ \\
$\mathrm{WBC}\left(\times 10^{3} / \mu \mathrm{L}\right)$ & $6.54 \pm 0.83$ & $8.87 \pm 1.00$ & $8.24 \pm 1.40$ & $6.83 \pm 0.33$ \\
$\mathrm{Platelets}\left(10^{5} / \mu \mathrm{L}\right)$ & $1.15 \pm 0.09$ & $1.19 \pm 0.11$ & $1.20 \pm 0.10$ & $1.01 \pm 0.08$ \\
Neutrophils $(\%)$ & $32.00 \pm 2.88$ & $32.20 \pm 4.82$ & $33.40 \pm 0.55$ & $30.40 \pm 5.12$ \\
Lymphocytes $(\%)$ & $66.60 \pm 2.50$ & $66.20 \pm 4.45$ & $64.60 \pm 4.45$ & $68.40 \pm 5.14$ \\
Eosinophils $(\%)$ & $0.80 \pm 0.37$ & $0.60 \pm 0.25$ & $1.00 \pm 0.45$ & $0.60 \pm 0.40$ \\
Monocytes $(\%)$ & $0.60 \pm 0.25$ & $1.00 \pm 0.32$ & $1.00 \pm 0.55$ & $0.60 \pm 0.40$ \\
\hline
\end{tabular}

Table 2: Effect of 30 days treatment with varying doses of MEVA on Plasma Biochemical Parameters (n

\begin{tabular}{|c|c|c|c|c|}
\hline \multicolumn{5}{|c|}{$=6, * p<0.05)$} \\
\hline Parameters & Control & $50 \mathrm{mg} / \mathrm{kg}$ & $100 \mathrm{mg} / \mathrm{kg}$ & $150 \mathrm{mg} / \mathrm{kg}$ \\
\hline Total Protein (gm \%) & $5.70 \pm 0.29$ & $5.82 \pm 0.19$ & $4.84 \pm 0.20^{*}$ & $5.82 \pm 0.21$ \\
\hline Albumin (gm \%) & $1.96 \pm 0.23$ & $2.38 \pm 0.15$ & $2.78 \pm 0.29 *$ & $2.92 \pm 0.17 *$ \\
\hline Globulin (gm \%) & & $3.20 \pm 0.37$ & $2.26 \pm 0.37 *$ & $2.86 \pm 0.28$ \\
\hline Creatinine $(\mu \mathrm{mol} / \mathrm{L})$ & $0.78 \pm 0.14$ & $0.66 \pm 0.55$ & $1.00 \pm 0.19$ & $1.20 \pm 0.20$ \\
\hline $\operatorname{AST}(\mu / \mathrm{L})$ & $20.40 \pm 3.23$ & $14.80 \pm 3.28$ & $16.20 \pm 0.86$ & $17.60 \pm 0.93$ \\
\hline $\operatorname{ALT}(\mu / \mathrm{L})$ & $17.80 \pm 1.93$ & $10.20 \pm 1.69^{*}$ & $12.20 \pm 0.80^{*}$ & $12.00 \pm 1.05^{*}$ \\
\hline
\end{tabular}

\section{Discussion}

The values obtained for RBC showed the non-significant effects of 30-day treatment of rats with MEVA on red blood cells (RBC) counts and indices relating to it ( $\mathrm{Hb}, \mathrm{PCV}, \mathrm{MCV}, \mathrm{MCH}$ and $\mathrm{MCHC}$ ) when compared with the control. This is an indication that there was no destruction of red blood cells and no change in the rate of production of RBC (erythropoiesis). This also shows that MEVA does not has the potential to stimulate erythropoietin release from the kidneys, which is the humoral regulator of RBC production (Polenakovic and Sikole, 1996). The non-significant effects of the 30-day treatment with MEVA at all doses also indicate that there were no change in the oxygen-carrying capacity of the blood and the amount of oxygen delivered to the tissues since RBC and haemoglobin $(\mathrm{Hb})$ are very important in transferring respiratory gases (De Gruchy, 1976). It has been reported that values of RBC and associated parameters lower than normal ranges are indicative of anemic conditions while higher values are suggestive of polycythemia (American Diabetes Association, 2000), thus, the 30-day treatment with MEVA may not have the potential to induce anemia or polycythemia. Also, the 30-day treatment of rats with MEVA at all treatment doses may not have adverse effects on the bone marrow, kidney and haemoglobin metabolism, since it has been reported that only substances which significantly affect the values of red blood cells and associated parameters would have effects on the bone marrow, kidney and haemoglobin metabolism (Young and Maciejewski, 1997).

The extract caused non - significant changes in the MCV and $\mathrm{MCH}$ values which could be an indication of absence of macrocytic anaemia since increased $\mathrm{MCV}$ an $\mathrm{MCH}$ values are known to be indicative of macrocytic anaemia. Also, MEVA caused non- significant change in the MCHC value which suggest and absence of hereditary spherocytosis since MCHC values are known to be elevated in hereditary spherocytosis.

The insignificant change in neutrophil count caused by extract probably indicates that the ability of the body to attack and destroy invading bacteria, viruses and other injurious agents (Phagocytosis) has not been compromised. The non-significant change in lymphocyte count suggests that the acquired immune responses of the body has not been compromised by the extract; while the non- significant change in monocyte count probably indicates that the phagocytic function of the body has not been compromised by extract. The non significant change in eosinophil count probably indicates that the anti-allergic and anti-parasitic injections response of the body have not been compromised by extract.

The insignificant change in TWBC count caused by MEVA suggests that the immune system has not been compromised. Contrary report was given by Adewusi and Afolayan (2009) in Pelargonium reniforme extract treated rats. Also, the insignificant change in the platelet count caused by extract could be an indication that it does not has the potential to stimulate thrombopoietin production (Li et al., 1999) with the hemostatic capability of the blood maintaining the status quo since platelets mediate in the blood-clotting mechanism. 
Two of the three doses of MEVA administered caused non-significant changes in total protein levels, which probably indicates that the buffering capacity of the blood and body fluid balance have not been compromised. Contrary report was given by Adewusi and Afolayan (2009) in Pelargonium reniforme extract treated rats. The extract caused significant increase in albumin level which suggests an enhancement in plasma level of metals, ions, fatty acids, amino acids, bilirubin and enzymes. Similar report was given by Adedapo et. al., (2007) in rats treated with $P$. amarus and $C$. anontifolius extracts. The extract caused significant decrease in the activity of ALT which probably indicates the hepato-protective potential of the extract. The extract caused insignificant change in creatinine level which suggests that the structural integrity and functions of the nephrons have not been compromised. The extract also caused non-significant change in the activity of AST which could indicate absence of tissue necrosis induction by the extract.

In conclusion, this study has shown that methanolic extract of Vernonia amygdalina could have beneficial potentialities on the blood chemistry of albino rats. However, its effect on human blood chemistry is unknown, nevertheless considering these findings in animal model, the consumption of Venonia amygdalina is recommended to people with blood disorder.

\section{References}

[1] Ainslie JR (1937): The list of plants used in native medicine in Nigeria, Imp. Forest. list. Oxford Inst. Paper 7 (mimeo)

[2] Akah PA, Okafor CI (1992): Hypoglycemic effect of Vernonia amygdalina in experimental rabbits Plant Med. Res. 1: 6 - 10.

[3] Akinpelu OA (1999): Antimicrobial activity of Vernonia amygdalina leaves. Fitoterapia 70 : 432 - 434.

[4] American Diabetes Association (2000): Nutrition recommendation and principles for people with diabetes mellitus clinical practice recommendations Diabetes care 23:543-6.

[5] Bosni ML, Osuji K, Tuah PO, Umunna NN (1995): Vernonia amygdalina as a supplement to teff straw fed to Ethiopian Menz sheep Agroforest. Syst. 31:229-241.

[6] Challand S, Willcox ML (2009): A clinical trial of the Vernonia amygdalina in the treatment of uncomplicated malaria. Journal of alternative and complementary medicine, 15: $1231-1237$.

[7] Dacie JV, Lewis SM (1991): Practical haematology, 7th edition ELBS with Churchill Livingston, England, pp 37-85.

[8] De Gruchy G.C. (1976): Clinical haematology in Medical Practice. Blackwell Scientific Publication. Oxford, London pp. 33 -57.

[9] Doumas BT, Watson W, Biggs HC (1971): Albumin standards and the measurement of serum albumin with bromocresol green. Clinica Chimica Acta 31, 87-96.

[10] Duncan JR, Praise KW, Mahaffey EA (1994): Veterinary Laboratory Medicine (Clinical Pathology) 3rd ed. Iowa State University Press, U.S.A.

[11] Jain NC (1986): Schalm's Veterinary Haematology 4th ed. Lea and Fabiger, Philadelphia.

[12] Li Y., Xia I., Kuter D.J. (1999): Interaction of thrombopoietin with the platelet complements receptor in plasma: binding, internalization, stability and pharmacokinetics. Brit J. Haematol 106: 345.

[13] Mitruka BM, Rawnsley H (1977): Clinical, biochemical and haematological references values in normal experimental animals. Masson Publishing USA Inc. Pp. 53-54

[14] Nwajo HU, Nwokoro E.A (2004): Antidiabetic and biochemical effects of aqueous extract of Vernonia amygdalina leaf in normoglycaemic and diabetic rats. J. Innov. Life Sci. 7: 6-10.

[15] Polenakovic M., Sikole A. (1996): Is erythropoietin a survival factor for red blood cells? J. Am. Soc Nephrol 7(8): 1178-1182.

[16] Reinhold JG (1953): Manual determination of serum total protein, albumin and globulin fractions by the Biuret method Standard Methods of Clinical Chemistry (Academic Press, New York).

[17] Tekoba AM, Onabanjo AO, Amole OO, Emeka PM (2002): Analgesic and antipyretic effects of the aqueous extract of Vernonia amygdalina. West Afri J. Pharm. 16: 68 - 74

[18] Tietz NW, Prude EL, Sirgard - Anderson O (1994): Textbook of clinical chemistry. Ed. Burtis C.A. and Ashwood E.R. pp 1354 1374. W.B. Saunders Company, London.

[19] Young N.S., Maciejewski J. (1997): The path physiology of acquired aplastic anemia. New Eng. J. Med., $336: 1365$. 